Cezary Kulesza

Uniwersytet w Bialymstoku

\title{
SYSTEMY WYBORU I MIANOWANIA SĘDZIÓW A PROBLEM ICH NIEZAWISKOŚCI - DOŚWIADCZENIA AMERYKAŃSKIE, ANGIELSKIE I NIEMIECKIE
}

\section{Uwagi wstępne}

W literaturze przedmiotu wskazuje się na różne systemy powoływania sędziów w krajach europejskich i USA: nominacji przez władzę wykonawczą (executive appointment), przez wybory (bezpośrednie lub pośrednie) w drodze kariery służbowej w zawodzie sędziowskim (career or civil service judiciary), przez nominację udziałową lub parytetową (shared or parity appointments) oraz nominowania przez komisje sędziowskie.

Systemy parytetowe opierają się na obsadzaniu stanowisk sędziowskich w sposób proporcjonalny w oparciu o określone kryteria, takie jak: partia polityczna, terytorium, pochodzenie etniczne lub płeć. Natomiast nominacja udziałowa polega na przyznaniu uprawnienia do powoływania sędziów w ręce różnych instytucji, jak na przykład przez obsadzania stanowisk sędziów w połowie przez prezydenta, a w drugiej połowie przez członków jednej z izb parlamentu. Te modelowe rozwiązania występują, ze względu na różnorodność konstytucji przyjętych w poszczególnych krajach, w różnych formach mieszanych, co powoduje trudności w jednoznacznym zaliczeniu ich do poszczególnych systemów. ${ }^{1}$

Systemy parytetowe i udziałowe są stosowane w różnych konfiguracjach w krajach europejskich przy obsadzaniu najwyższych organów sądowniczych pełniących rolę trybunałów konstytucyjnych bądź sądów najwyższych. Elementy tych metod można znaleźć także w wyborach do międzynarodowych trybunałów karnych, które to wybory są uważane w literaturze przedmiotu i orzecznictwie za istotną gwarancję niezawisłości i bezstronności zasiadających w nich sędziów oraz rzetelnego procesu. ${ }^{2}$

\footnotetext{
1 M.L. Volcansek, Judicial Elections and American Exceptionalism, Deapaul Law Review 2010-2011, vol. 60, s. 805-806 i podana tam literatura.

2 P. Wiliński, H. Kuczyńska, Rzetelny proces karny w orzecznictwie międzynarodowych trybunałów karnych, (w:) P. Wiliński (red.), Rzetelny proces karny, Warszawa 2009, s. 188-189.
} 
Przy analizie prawnoporównawczej należy także wskazać na różnice pomiędzy rolą sędziego w rozstrzyganiu spraw karnych (na których skoncentrowano się w niniejszym opracowaniu) w systemie anglosaskim i systemach prawnych Europy kontynentalnej. Generalnie rzecz ujmując, sędzia angielski czy amerykański jest bezstronnym arbitrem $\mathrm{w}$ kontradyktoryjnym procesie sądowym rozstrzygającym spór pomiędzy obroną a oskarżeniem, zaś w analizowanym tu niemieckim systemie wymiaru sprawiedliwości (zaliczanym przez doktrynę do systemów tradycji civil law) sędzia jest zobowiązany do dążenia z urzędu do wykrycia prawdy materialnej, bez względu na inicjatywę dowodową stron. ${ }^{3}$

\section{Wpływ systemów wyboru i nominacji sędziów w USA na niezawisłość sędziowską}

W USA podstawową metodą powoływania sędziów federalnych jest ich nominowanie przez Prezydenta, który działa za zgodą i radą Senatu, zaś sam proces decyzyjny posiada charakter polityczny, gdyż ponad $90 \%$ sędziów powołanych przez prezydenta pochodzi z jego partii. ${ }^{4}$ Przy obsadzaniu stanowisk w sądach federalnych (dystryktowych i apelacyjnych) Prezydent korzysta z pomocy Prokuratora Generalnego (Attorney General), zaś ich merytoryczną oceną zajmuje się Komitet ds. Sądownictwa Federalnego Amerykańskiego Stowarzyszenia Prawników (ABA Standing Committee on the Federal Judiciary). Podobnie wygląda procedura nominacji sędziów Federalnego Sądu Najwyższego, których wybór jest bardzo istotny dla Prezydenta, gdyż Sąd ten (pełniąc rolę także Sądu Konstytucyjnego) swoim orzecznictwem wpływa na funkcjonowanie całego systemu politycznego kraju. W obsadzaniu sędziów w tej najwyższej instancji sądowniczej Prezydenta wspomaga nie tylko Attorney General i opiniujący kandydatury Komitet ds. Sądownictwa Federalnego ABA i Senacki Komitet Sądowniczy, ale także sami sędziowie Sądu Najwyższego, działając z własnej inicjatywy bądź na prośbę Prezydenta. W ostatnich latach proces nominacji sędziów Sądu Najwyższego podlegał ewolucji, w toku której zmieniała się rola poszczególnych instytucji doradczych biorących udział w tej procedurze (w szczególności Komitetu ABA). Cechą charakterystyczną tego procesu jest zjawisko silnego zaangażowania w proces nominacji sędziów $\mathrm{SN}$ różnych grup nacisku, które mogą mieć znaczny wpływ na decyzję Senatu o odrzuceniu kandydata. ${ }^{5}$

Jednakże w przypadku nominacji przez Prezydenta sędziów federalnych nie występuje problem zagrożeń dla ich niezawisłości, gdyż zgodnie z III Poprawką do

3 Na temat różnic pomiędzy rolą sędziego kontynentalnego i anglosaskiego zob. W. Gontarski, Porównanie niekontradyktoryjnego (kontynentalnego) procesu karnego z procesem kontradyktoryjnym (anglosaskim), (w:) Proces karny. Rozwiązania modelowe w ujęciu prawnoporównawczym. System prawa karnego procesowego, P. Kruszyński (red.), TII, Warszawa 2014, s. 145-158.

$4 \quad$ I. Kraśnicka, A. Ludwichowska, Wprowadzenie do systemu prawa Stanów Zjednoczonych, Toruń 2012, s. 188189 i podana tam literatura.

$5 \quad$ Ibidem, s. 190-192 i podana tam literatura. 
Konstytucji USA pełnią oni swoją funkcję dożywotnio. Natomiast inaczej wygląda sytuacja w przypadku powoływania sędziów sądów stanowych. Na tle różnorodności rozwiązań przyjętych w poszczególnych stanach można mówić o trzech podstawowych modelach selekcji tych sędziów ${ }^{6}$ :

1) mianowania przez gubernatora bądź legislaturę stanową

2) w drodze powszechnych wyborów:

- w oparciu o kryterium partyjne (partisan election), gdzie przy nazwisku sędziego figuruje jego przynależność do określonej partii bądź

- niepartyjne (nonpartisan elections), gdzie brak jest takiej adnotacji.

3) przez wybór merytoryczny (Merit Selection) znany także jako Plan Missouri polegający generalnie na wyborze kandydatów na sędziów w drodze specjalnej procedury przez komitety legislacyjne w oparciu o dokonania i kryteria merytoryczne potencjalnych sędziów. Ostatecznej nominacji dokonuje zwykle gubernator stanu spośród trzech-pięciu przedstawionych mu przez komitet kandydatów.

W doktrynie amerykańskiej sygnalizuje się szereg problemów związanych z wyborami i nominacjami sędziów stanowych, w kontekście z jednej strony ich niezależności, z drugiej zaś odpowiedzialności. Podkreśla się, że już od 200 lat trwa żywa dyskusja o właściwej roli sędziów w USA. Zwolennicy silnego i niezawisłego sądownictwa od lat uważają, że rolą sędziów jest wierna interpretacja prawa i konstytucji, niezależnie od takich zewnętrznych czynników, jak polityka czy opinia społeczna. Dlatego też postulują oni, aby sędziowie nie byli wybierani w wyborach powszechnych, lecz mianowani. Z kolei zwolennicy odpowiedzialności sędziów przed społeczeństwem twierdzą, że sędziowie są wykonawcami polityki rządowej, działającymi w ustroju demokratycznym i dlatego powinni odpowiadać bezpośrednio przed społeczeństwem za swoje działania w drodze periodycznych wyborów, bez względu na to, jaki to ma wpływ na ich niezawisłość. ${ }^{7}$

Wśród mankamentów powszechnych wyborów sędziów wymienia się m.in. niską świadomość wyborców i wiedzę odnośnie do kandydatów na sędziów, wysokie koszty kampanii wyborczych i wynikające z tego faktu niebezpieczeństwo kierowania się przez wybranych sędziów w ich późniejszym orzecznictwie sympatiami wobec donatorów tych kampanii. ${ }^{8}$ Warto tu wskazać na orzeczenie w sprawie Republican Party of Minnesota v. White (536 U.S. 765, 788 (2002), w którym Sąd Naj-

Na temat rozwoju i bliższej charakterystyki tych form selekcji sędziów zobacz szerzej zamieszczony w tym opracowaniu tekst I. Kraśnickiej, Systemy wyborów sędziów stanowych w USA oraz J. Rosinek, Some Thoughts on the Problems of Judicial Selections, Court Review, Summer 2004, s. 20-24.

7 D.C. Brody, The Use of Judicial Performance Evaluation Enhance Judicial Accountability, Judicial Independence, and Public Trust, :Denver University Law Review", vol. 86, 2008-2009, s. 115-117 oraz C.G. Geyh, The Endless Judicial Selection Debate and Why it Matters for Judicial Independence, „The Georgetown Journal of Legal Ethics" vol. 21, 2008, s.1259-1263 i podana tam literatura.

8 C.G. Geyh, The Endless Judicial Selection Debate..., op. cit., s. 1265-1270 i podane tam wyniki badań. 
wyższy USA orzekł, że kandydaci na sędziów mają prawo wynikające z I Poprawki do Konstytucji do wypowiadania swoich poglądów co do kwestii, które będą rozważali później, już jako sędziowie. Z kolei w sprawie Caperton v. A.T. Massey Coal Co (556 U.S. 868,881-86 (2009)) Sąd Najwyższy USA po raz pierwszy stwierdził, że zachowanie odnoszące się do kampanii wyborczej sędziego może naruszać prawa stron do rzetelnego procesu (due process rights). Sąd ten przyjął, że „poważne ryzyko stronniczości”, które ,jest zbyt wysokie, aby być tolerowane zgodnie z konstytucją" powstało w sytuacji, kiedy właśnie wybrany Sędzia Sądu Apelacyjnego West Virginii B. Benjamin rozpoznał apelację dotyczącą jego najważniejszego sponsora w wyborach sędziowskich, Don Blankinshipa. Sponsor ten wydał wiele milionów na sukces wyborczy sędziego Benjamina wiedząc, że jego sprawa trafi zaraz po wyborach do sądu apelacyjnego. ${ }^{9}$

Jednakże prawdziwe niebezpieczeństwo dla niezawisłości i bezstronności sądów stanowych upatruje się nie w ich pierwszej selekcji (w drodze wyborów powszechnych, nominacji bądź procedurze Missouri) na czas określonej kadencji, lecz w metodzie ich powołania na dalszą kadencję (retention). Pod koniec ubiegłego wieku w USA w stanowych sądach apelacyjnych i sądach I instancji (hrabstw i okręgowych) znakomita większość sędziów podlegała różnym formom selekcji i powoływania na nową kadencję (selection and retention).

Tabela 1. Systemy selekcji i retencji sędziów stanowych w USA

\begin{tabular}{|c|c|}
\hline \multicolumn{2}{|c|}{$\begin{array}{c}\text { Sądy Apelacyjne } \\
\text { Łącna liczba sędziów apelacyjnych: } 1.243\end{array}$} \\
Łączna liczba tych, którzy podlegali różnym formom wyborów: $1.084(87 \%)$ \\
Łączna liczba tych, którzy podlegali wyborom konkurencyjnym: $659(53 \%)$
\end{tabular}

Źródto: J. Rosinek, Some Thoughts on the Problems of Judicial Selections, Court Review, Summer 2004, s. 21. 
W literaturze przedmiotu wysuwa się więc argumenty, że fakt, iż sędzia stanowy w sytuacji pierwszego powołania (bez względu na metodę selekcji), z reguły na okres kilkuletni, może obawiać się orzekać niezawiśle i bezstronnie, narażając się na niełaskę bądź wyborców, bądź też nominującego go organu wykonawczego. Przeciwstawia się więc leżący u podstaw metody powszechnych wyborów sędziów „ludowy konstytucjonalizm” (popular constitutionalism) prawdziwemu konstytucjonalizmowi i ucieleśniającej go w sferze procesu karnego idei rzetelnego procesu (due process of law). ${ }^{10}$

W kwestii wpływu metody powoływania (i retencji) sędziego stanowego na jego późniejszą interpretację prawa brak jest jednoznacznych badań o istnieniu takiej zależności, co powoduje ciągły spór między zwolennikami takiej tezy, ${ }^{11}$ jak i jej przeciwnikami. ${ }^{12}$ Jednakże większość autorów prezentuje jednolity pogląd o istotnej roli, jaką gra dla zachowania niezawisłości i bezstronności sędziów ich etyka, której formą instytucjonalną jest opracowany przez ABA Modelowy Kodeks Postępowania Sędziego (The American Bar Association's Model Code of Judicial Conduct). ${ }^{13}$

\section{Powoływanie sędziów w Anglii i Walii a ustawa o reformie konstytucyjnej z 2005 r.}

W systemie wymiaru sprawiedliwości Anglii i Walii pracujący społecznie sędziowie laicy (magistrates) zasiadający w sądach magistrackich (których w roku 2007 było ok. 30.000), zgodnie z ustawą o sądach z 2003 r. (Courts Act 2003) są powoływani w imieniu Królowej przez Lorda Kanclerza (Lord Chancellor). Przy podejmowaniu decyzji o powołaniu Lord Chancellor stosuje przede wszystkim kryterium, czy kandydat posiada charakter i zdolności do pracy jako sędzia oraz czy ze względu na to jest akceptowany przez środowisko sędziowskie. Jednocześnie taki tryb powoływania sędziów przez władzę wykonawczą był i jest krytykowany w doktrynie ze względu na fakt, że nominowani kandydaci najczęściej pochodzą z wyższych klas społecznych i nie są reprezentatywni dla środowiska (w szczególności udział wśród sędziów mniejszości etnicznych wynosi kilka procent). ${ }^{14}$ Przed zatrudnieniem sędziowie przechodzą jednoroczny kurs podstawowego szkolenia odnośnie obowiązków, jakie będą wykonywać. Jego celem jest dostarczenie im podstawowej wiedzy o prawie i postępowaniu dowodowym, o zasadach prowadzenia spraw i wyrokowania oraz o roli innych uczestników procesu karnego (np. sekretarza sądu i personelu sądowego oraz reprezentantów stron procesowych). Sędziów

\footnotetext{
10 M.H. Redish, J. Aronoff, The Real Constitutional Problem..., op. cit., s. 33-45.

11 Zob. oprócz powołanego wyżej M.H. Redisha i J. Aronoffa także P. Bruhl and Ethan J. Leib, Elected Judges and Statutory Interpretation, „University of Chicago Law Review”, vol. 79 (2012), s. 1215-1230.

12 Bertrall L. Ross II, Reconsidering Statutory Interpretive Divergence between Elected and Appointed Judges, „University of Chicago Law Review", vol. 89 (2013), s. 53-80.

13 Zob. np. C.G. Geyh, The Endless Judicial Selection Debate..., op. cit., s. 1259 i nast.

14 J. Sprack, A Practical Approach to Criminal Procedure, Oxford 2008, s. 90-91.
} 
laików odwołuje Lord Chancellor w przypadkach przewidzianych przez Courts Act 2003 (art. 10), takich jak niezdolność do wykonywania zawodu lub zachowanie niegodne sędziego i niedochowywaniu należytych standardów kompetencji i wykonywaniu ich funkcji orzeczniczych.

Natomiast zawodowi sędziowie sądów magistrackich (district judges - wcześniej zwani stipendary magistrates) są profesjonalistami uzyskującymi wynagrodzenie za wykonywanie swoich funkcji. Są oni powoływani przez Królową na podstawie rekomendacji Lorda Chancellora spośród adwokatów (barristers i solicitors) mających co najmniej 7-letni staż pracy w tym zawodzie. Jest ich około 140 i są wspomagani przez liczną rzeszę zastępców, zatrudnionych na część etatu i oczekujących na zatrudnienie w pełnym wymiarze. District judges pracują do osiągnięcia wieku emerytalnego (zasadniczo do ukończenia 70. roku życia), ale mogą być pozbawieni wcześniej urzędu przez Lorda Chancellora w przypadku niezdolności do sprawowania swojej funkcji bądź niegodnego zachowania (inability or misbehaviour).

W sądach Królewskich (Crown Courts) stanowiących pierwszą instancję w poważnych sprawach wymagających aktu oskarżenia i instancję odwoławczą od orzeczeń wydanych przez magistrates' courts zasiadają sędziowie Wysokiego Sądu (High Court) rozpoznający najważniejsze sprawy (jest ich około 20) oraz sędziowie okręgowi (circuit judges), rozpoznający ok. $80 \%$ spraw i zatrudnieni w niepełnym wymiarze recorders, którzy mogą łączyć funkcję sędziego z praktyką adwokacką. Circuit judges są powoływani przez Królową na podstawie rekomendacji Lorda Chancellora i jako sędziowie pełnoetatowi muszą się legitymować przynajmniej 10- letnim stażem w sądownictwie bądź zajmować przed tym stanowisko w sądzie administracyjnym. Również oni mogą być przed osiągnięciem wieku emerytalnego pozbawieni urzędu przez Lorda Chancellora w przypadku niezdolności do sprawowania swojej funkcji bądź niegodnego zachowania. Podobnie jak sędziowie okręgowi recorders są powoływani przez Królową na podstawie rekomendacji Lorda Kanclerza spośród adwokatów posiadających przynajmniej 10-letni staż w zawodzie, jednakże na czas określony, do rozpoznawania określonej liczby spraw i kiedy nie orzekają mogą wykonywać praktykę adwokacką.

Dominująca rola Lorda Chancellora przy nominowaniu i odwoływaniu sędziów wynikała przede wszystkim z faktu, że Anglia i Walia nie posiadały konstytucji, jako aktu prawnego najwyższej rangi, który w krajach kontynentu europejskiego zwykle określa gwarancje niezawisłości sędziowskiej. W związku z inkorporacją do angielskiego systemu prawnego na mocy Human Rights Act 1998 postanowień do systemu prawnego Anglii i Walii Europejskiej Konwencji Praw Człowieka powstała potrzeba ustawowego zagwarantowania niezawisłości sądów angielskich (zgodnie z wymogiem art. 6 ust. 1 EKPCz), w tym stworzenie instytucji Sądu Najwyższego. Wymogu takiego nie spełniał Komitet Apelacyjny Izby Lordów (Appelate Committee of the House of Lords) jako zależny od wyższej izby Parlamentu. Sytuacja uległa zmianie po uchwaleniu w 2005 r. ustawy o reformie konstytucyjnej (Constitutio- 
nal Reform Act 2005 - powoływanej dalej jako CRA) wprowadzającej do systemu prawnego Zjednoczonego Królestwa instytucję Sądu Najwyższego (U.K. Supreme Court). Akt ten, zgodnie z rządowym uzasadnieniem rządowego projektu, ,ukształtował na nowo stosunki między władzą sądowniczą i wykonawczą nadając im nowoczesny kształt". ${ }^{15} \mathrm{~W}$ sferze wyborów sędziów istotnym było powołanie Komisji Nominacji Sędziowskich (Judicial Appointments Commission), która ograniczyła rolę Lorda Kanclerza do akceptowania bądź wyjątkowo odrzucania jej rekomendacji kandydatów na urząd sędziego. CRA zmieniła także w sposób istotny system powoływania i dyscyplinowania sędziów przez powołanie instytucji ombudsmana (,,judicial appointments and conduct ombudsman").

W artykule 1 CRA określono obowiązki wszystkich członków rządu, a szczególnie Lorda Kanclerza, w dziedzinie zapewnienia gwarancji niezawisłości sędziowskiej. Niezawisłość sędziowska jest określana w literaturze angielskiej jako niezależność sędziów we wspieraniu praworządności i ochronie praw człowieka $\mathrm{i}$,zapewnienie bezstronności w każdej sprawie z jaką ma do czynienia i w każdych warunkach". Uważa się, że nie jest to przywilej samych sędziów, a raczej oznacza ,pprawo społeczeństwa i obywatela, z drugiej zaś obowiązek sądownictwa i sędziego" (,, a right of the people and of a person and a duty of the judiciary and a judge”). ${ }^{16}$

Wskazując na ograniczone możliwości Lorda Kanclerza (jako członka rządu, który po reformie nie musi być nawet prawnikiem) w ochronie niezawisłości w literaturze podkreśla się w tej mierze istotną rolę samych sędziów, jawności i odpowiedzialności w ich działaniach. Pomocne powinny tu być zasady etyki sędziowskiej, które zostały zebrane i opracowane w 2002 r. w formie „Przewodnika etyki sędziowskiej" (Guide to Judicial Conduct) przyjętego przez judykaturę Anglii i Walii w październiku 2004 r. $^{17}$

W literaturze angielskiej podkreśla się także istotną rolę, jaką w ochronie niezawisłości sędziowskiej ma odegrać ,, aktywny, otwarty i odpowiedzialny” Sąd Najwyższy, który może być bardziej efektywny w ochronie niezawisłości sędziów niż minister rządu - „,nawet noszący dostojny tytuł Lorda Kanclerza” (,A proactive, open, and accountable Supreme Court is likely to be more effective in protecting judicial independence than a government minister - even one with the exalted title of lord chancellor'”). ${ }^{18}$

\footnotetext{
15 D. Woodhouse, United Kingdom. The Constitutional Reform Act 2005 - defending judicial independence the English way, „The International Journal of Constitutional Law”, vol. 5, 2007, s. 153-154.

16 D. Woodhouse, United Kingdom. The Constitutional Reform Act 2005..., op. cit., s. 156-157 i podana tam literatura.

17 Przewodnik etyki sędziowskiej. Zasady etyki dla sędziów Anglii i Walii. Guide to Judicial Conduct (z wprowadzeniem R. Sarkowicza), Warszawa 2007.

18 D. Woodhouse, United Kingdom. The Constitutional Reform Act 2005..., op. cit., s. 165.
} 


\section{Systemy powoływania sędziów w Niemczech oraz konstytucyjne gwarancje ich niezawisłości}

Wybór dla potrzeb niniejszej analizy systemu niemieckiego wynika przynajmniej z następujących względów. Po pierwsze, jest to klasyczny system prawa kontynentalnego (civil law) hołdującego w sferze procesu karnego zasadzie prawdy materialnej. Po drugie, państwo to ma ustrój związku (federacji) krajów o pewnej autonomii (także w określaniu sposobu powoływania sędziów), którą jednak trudno porównywać z samodzielnością stanów w USA.

Obecnie w RFN wśród sądów powszechnych orzekających w sprawach karnych można wyróżnić sądy rejonowe (Amtsgerichte), krajowe (Landgerichte) i wyższe sądy krajowe (Oberlandesgerichte - OLG) ${ }^{19}$ Sprawami karnymi zajmuje się także związkowy Sąd Najwyższy (Bundesgerichtshof - BGH), krajowe trybunały konstytucyjne (Landesverfassungsgerichte) i związkowy Trybunał Konstytucyjny (Bundesverfassungsgericht - BVerfG).

Ponieważ o wyborach sędziów, na które ma wyraźny wpływ czynnik polityczny można mówić przede wszystkim w przypadku trybunałów konstytucyjnych, więc w tym miejscu wypada poświęcić im kilka uwag. Status Trybunału Konstytucyjnego RFN jest określony zasadniczo w art. 92-94 Konstytucji RFN (Grundgesetz - GG). Art. 94 ust. 1 GG określa, że połowę sędziów Trybunału wybiera Parlament (Bundestag), a połowę Rada Związku (Bundesrat) kwalifikowaną większością 2/3 głosów. Natomiast szczegółowe zasady wyboru tych sędziów określa wydana w oparciu o art. 94 ust. 2 GG ustawa o ustroju Trybunału (BverfGG). Formalnie na stanowisko sędziego Trybunału powołuje Prezydent RFN, ale jego rola sprowadza się jedynie do wykonania decyzji Parlamentu i Rady. Wymóg większości 2/3 głosów w organach wyborczych ma stanowić gwarancję bezpartyjności (Unparteilichkeit) sędziów i zapewnić ponadpartyjność składu Trybunału (Überparteilichkeit). W rezultacie przyjęcie takiej metody powoduje, że mniejsze frakcje parlamentarne mogą liczyć na obsadzenie 1-2 stanowisk sędziowskich w Trybunale. Rolę doradczą przy wyborach pełnią także urzędujący sędziowie, jednak ich propozycje (listy) kandydatur są niewiążące dla organów wyborczych. W doktrynie niemieckiej znaczne upolitycznienie procedur wyborczych do $B \operatorname{Verf} G$ jest krytykowane, jako obniżające szanse sędziów „politycznie neutralnych” i postuluje się większą transparentność takich wyborów oraz uwzględnianie stanowiska urzędujących sędziów Trybunału. ${ }^{20}$

W RFN gwarancje niezawisłości sędziowskiej zawarte są w Konstytucji, przede wszystkim w jej art. 97 stanowiącym w ust. 1 że sędziowie są niezawiśli i podlegają

\footnotetext{
19 Odnośnie właściwości i zasad funkcjonowania niemieckich sądów powszechnych w sprawach karnych zob. np. Ł. Malinowski, Postępowanie po wniesieniu aktu oskarżenia do sądu, (w:) Proces karny. Rozwiązania modelowe w ujęciu prawnoporównawczym, op. cit., s. 422-436. 
tylko ustawom. ${ }^{21} \mathrm{~W}$ doktrynie i orzecznictwie BVerfG przyjmuje się, że pojęcie niezawisłości sędziowskiej obejmuje zarówno aspekt materialny (art. 97 ust. $1 \mathrm{GG}$ ), jak i osobisty (art. 97 ust. 2 GG) gwarantujący zasadniczo dożywotnią nieusuwalność sędziego z zajmowanego stanowiska (zob. np. stanowisko tego Trybunału zajęte w postanowieniu z dnia 23 maja 2012 r., 2 BvR 610/12, BvR 625/12, postanowieniu z dnia 14 lipca 2006 r., 2 BvR 1058/05 oraz innych orzeczeniach wskazanych w dalszej części niniejszego opracowania ${ }^{22}$ ).

Związkowy Trybunał Konstytucyjny zajmował się kwestią zgodności z konstytucyjną zasadą niezawisłości sędziowskiej regulacji krajowych dotyczących wyborów do związkowych trybunałów konstytucyjnych. W postanowieniu z dnia 23 lipca 1998 r. (1 BvR 2470/94) BVerfG uznał za zgodne z Konstytucją RFN zasady wyboru sędziów Trybunału Konstytucyjnego Bawarii przez parlament tego kraju związkowego zwykłą (a nie kwalifikowaną) większością głosów. Trybunał podkreślił w tym orzeczeniu, że zasadnicze znaczenia dla niezawisłości ma nie sposób wyboru sędziów, lecz przestrzeganie przez nich zasad godności i etyki zawodu sędziego.

Natomiast przy selekcji sędziów sądów powszechnych w Niemczech obowiązuje model kariery sędziowskiej. Absolwenci prawa po zakończeniu studiów są zobowiązani zdać egzamin końcowy i ci z najlepszymi notami mają szansę starania się o stanowisko w sądach najniższej instancji (Amtsgerichte). W każdym kraju członkowskim(Bund) RFN istnieją doraźne komisje ds. wyboru sędziów zawodowych, których podstawy działania określa art. 95 ust. 2 Konstytucji i ustawa o wyborze sędziów (Richterwahlgesetz - RiWG).

Kandydaci na sędziów są przedstawiani przez właściwego ministra sprawiedliwości kraju związkowego bądź przedstawicieli komisji wyborczej, a następnie opiniowani przez prezydium sądu, w którym kandydat ma objąć stanowisko. Komisja wyborcza dysponuje aktami personalnymi kandydata oraz dokumentacją jego dotychczasowej kariery i osiągnięć zawodowych. W oparciu o nie ocenia kwalifikacje zawodowe i predyspozycje osobiste kandydata do sprawowania urzędu, a następnie podejmuje uchwałę $\mathrm{w}$ tajnym głosowaniu. Jeśli minister zgadza się $\mathrm{z}$ wybraną kandydaturą, wówczas przedstawia ją prezydentowi Związku, a ten powołuje go do urzędu sędziego, co wymaga nadto kontrasygnaty kanclerza RFN bądź właściwego ministra (art. 60 i $58 \mathrm{GG}$ ).

Również w Niemczech, jak wskazuje się w cytowanej wcześniej literaturze przedmiotu, podnoszone są głosy krytyczne wobec tego trybu selekcji sędziów, zarzucające mu brak przejrzystości i kierowania się przy wyborze nie tylko kryteriami wiedzy fachowej kandydata, lecz i jego orientacją polityczną. Ponadto należy za-

21 Zob. np. M. Fornauf, Die Marginalisierung der Unabhängigkeit der Dritten Gewalt im System des Strafrechts, Frankfurt am Main 2010, s. 79-83. Zob. także wyrok Niemieckiego Trybunału Konstytucyjnego z dnia 23.05.2012 r. BVerfG, 2 BvR 610/12 (ust. 12-14). 22 Orzeczenia Związkowego Trybunału Konstytucyjnego są powoływane z jego oficjalnej strony internetowej: www. 
uważyć, że Konstytucja RFN pozostawia ustawodawstwom krajów związkowym znaczną swobodę w kształtowaniu szczegółowych regulacji selekcji sędziów sądów powszechnych (art. 98 ust. 3-5 GG).

Sędziowie sądów powszechnych w Niemczech są powoływani na swoje stanowisko zasadniczo dożywotnio, aczkolwiek istnieje tu instytucja mianowanego na okres kilkuletni ,sędziego na próbę” (Proberichter), podobna do usuniętej z polskiego systemu wymiaru sprawiedliwości instytucji asesora sądowego.

Warto więc wskazać na wybrane orzecznictwo Związkowego Trybunału Konstytucyjnego odnoszące się do zasady niezawisłości sędziów sądów powszechnych. W orzecznictwie tym wskazuje się, że „sędzia na próbę” wprawdzie nie korzysta ze wszystkich atrybutów niezawisłości sędziowskiej, lecz ma pełne prawo wraz z sędziami z innych krajów związkowych do ubiegania się o objęcia dożywotniego stanowiska sędziego w kraju siedziby sądu, w którym wykonuje swoje obowiązki. $\mathrm{W}$ dotyczącym tego problemu postanowieniu BVerfG z dnia 4 grudnia 2006 r. (2 BvR 2494/06) Trybunał uznał za zgodne z Konstytucją RFN regulacje kraju Schlezwig-Holstein zasadniczo wykluczające $\mathrm{z}$ kręgu ubiegających się o stanowisko sędziego sądu rejonowego w tym kraju związkowym kandydatów mieszkających poza nim (w tym pełnoprawnego sędziego z Dolnej Saksonii).

Z kolei w postanowieniu z 16 marca 2005 r.(2 BvR 957/05) Związkowy Trybunał Konstytucyjny uznał za zgodne z Konstytucją RFN (a w szczególności jej art. 97) rozporządzenie Ministerstwa Sprawiedliwości Nordrhein-Westfalen uzależniające powołanie sędziego sądu krajowego na stanowisko sędziego wyższego sądu krajowego (Oberlandesgericht) od wcześniejszego delegowania do tego sądu.

Wśród orzeczeń odnoszących się do czynników wewnętrznych, wynikających z organizacji pracy w samych sądach, a mogących mieć wpływ na niezawisłość i bezstronność sędziów należy z jednej strony wskazać na orzeczenia uznające, że komputeryzacja sądów i elektroniczne przetwarzanie danych zawartych w aktach sądowych nie narusza swobody pracy orzeczniczej sędziów (postanowienie BVerfG z dnia 6 października 2011 r., 2 BvR 2576/11), z drugiej zaś stwierdzające, że sędziemu korzystającemu z gwarancji niezawisłości przysługuje prawo podmiotowe wynikające $\mathrm{z}$ art. 101 ust. 1 GG chroniące go przed nieracjonalnym obciążeniem go pracą przez prezesa sądu (postanowienie BVerfG z dnia 23 maja 2012 r., 2 BvR $610 / 12)$.

\section{Wnioski końcowe}

Przeprowadzona w niniejszym opracowaniu, siłą rzeczy skrótowa, analiza systemów prawnych USA, Anglii i Walii oraz Niemiec pozwala na wysnucie generalnego wniosku, że stosowane w nich metody wyboru i nominacji sędziów mogą wywierać skutki w sferze niezawisłości i bezstronności sędziowskiej. Rozwiązania przyjęte 
w prawie anglosaskim i kontynentalnym (na przykładzie Niemiec) implikują różnorodne zagrożenia dla tych podstawowych cech statusu prawnego i społecznego sędziów. Szczególne niebezpieczeństwa zdają się występować w amerykańskim systemie wymiaru sprawiedliwości, gdzie zakorzenione w idei „ludowego konstytucjonalizmu" metody wyboru i reelekcji sędziów stanowych zagrażać mogą gwarancjom rzetelnego procesu. Badania amerykańskie w znacznym stopniu uzasadniają tezę, że szczególnie w przypadku wyborów bezpośrednich sędziów stanowych czują się oni związani w swojej działalności orzeczniczej opiniami swoich wyborców. Takie niebezpieczeństwo jest szczególnie realne w tych stanach, gdzie stanowiska sędziowskie są kadencyjne, a sami sędziowie podlegają procedurom reelekcji, gdzie istotna jest ocena ich pracy przez wyborców bądź organ nominujący na drugą kadencję. Od wpływów takich wolni są jedynie sędziowie federalni (a w szczególności Sądu Najwyższego USA), gdyż Konstytucja zapewnia im dożywotnie sprawowanie ich funkcji.

Z kolei w angielskim systemie prawnym można zauważyć osłabienie dominującego wpływu czynnika administracyjnego, czyli Lorda Kanclerza (działającego w imieniu własnym lub Królowej) na nominacje sędziów i wzrost wpływu samorządu sędziowskiego na procedury selekcyjne. Istotną zmianę przyniosła tu ustawa konstytucyjna z 2005 r. wprowadzająca nie tylko Komisję Nominacji Sędziowskiej, lecz także instytucję Sądu Najwyższego, którego zadaniem jest m.in. troska o zapewnienie gwarancji niezawisłości sędziowskiej. To z kolei uprawnia do postawienia być może kontrowersyjnej tezy, że rozwiązania angielskie w dziedzinie selekcji sędziów sądów powszechnych zbliżają się w tej mierze do metody kariery zawodowej, dominującej na kontynencie europejskim, a w szczególności przyjętej w Niemczech. Rozważania dotyczące niemieckiego systemu wymiaru sprawiedliwości wskazują na istotne znaczenie, jakie dla zapewnienia sędziom gwarancji niezawisłości i bezstronności ma nadanie tym gwarancjom rangi konstytucyjnej i ochrona w orzecznictwie Trybunału Konstytucyjnego.

We wszystkich analizowanych tu systemach prawnych organy władzy centralnej (Parlament, a w przypadku USA - Prezydent) zapewniły sobie dominujący wpływ na powoływanie najwyższych instancji sądowniczych. Jednakże powołane w niniejszym opracowaniu poglądy doktryny i orzecznictwo sądowe w USA, Anglii i Niemczech podkreślają, że uniwersalną gwarancją niezawisłości sędziów orzekających w sądach wszystkich instancji, jest kierowanie się przez nich zasadami godności i etyki zawodowej. 


\section{BIBLIOGRAFIA}

Brody D.C., The Use of Judicial Performance Evaluation Enhance Judicial Accountability, Judicial Independence, and Public Trust, Denver University Law Review, vol.86, 2008-2009

Bruhl P., Leib E.J., Elected Judges and Statutory Interpretation,University of Chicago Law Review, vol. 79, 2012

Fornauf M., Die Marginalisierung der Unabhängigkeit der Dritten Gewalt im System des Strafrechts, Frankfurt am Main 2010

Geyh C.G., The Endless Judicial Selection Debate and Why it Matters for Judicial Independence, The Georgetown Journal of Legal Ethics vol. 21, 2008

Gontarski W., Porównanie niekontradyktoryjnego (kontynentalnego) procesu karnego z procesem kontradyktoryjnym (anglosaskim), (w:) Proces karny. Rozwiązania modelowe w ujęciu prawnoporównawczym. System prawa karnego procesowego. T II (red. P. Kruszyński), Warszawa 2014

Judges, University of Chicago Law Review, vol. 89, 2013

Kraśnicka I, Ludwichowska A., Wprowadzenie do systemu prawa Stanów Zjednoczonych, Toruń 2012

Kraśnicka I., Systemy wyborów sędziów stanowych w USA, Białostockie Studia Prawnicze 2015

Malinowski $Ł$, Postępowanie po wniesieniu aktu oskarżenia do sądu, (w:) Proces karny. Rozwiązania modelowe w ujęciu prawnoporównawczym. System prawa karnego procesowego. T II (red. P. Kruszyński), Warszawa 2014

Przewodnik etyki sędziowskiej. Zasady etyki dla sędziów Anglii i Walii. Guide to Judicial Conduct (z wprowadzeniem R. Sarkowicza), Warszawa 2007

Redish M.H., Aronoff J., The Real Constitutional Problem with State Judicial Selection: Due Process, Judicial Retention, and The Dangers of Popular Constitutionalism, William \& Mary Law Review, vol. 56, 2014

Rosinek J., Some Thoughts on the Problems of Judicial Selections, Court Review, Summer 2004

Ross II B.L., Reconsidering Statutory InterpretiveDivergence between Elected and Appointed

Sprack J., A Practical Approach to Criminal Procedure, Oxford 2008

Volcansek M.L., Judicial Elections and American Exceptionalism, Deapaul Law Review, vol. 60, 2010-2011

Wiliński P., H. Kuczyńska H., Rzetelny proces karny w orzecznictwie międzynarodowych trybunałów karnych (w:) Rzetelny proces karny (red. P. Wiliński), Warszawa 2009

Wittereck F., Die Verwaltung der Dritten Gewalt, Tübingen 2006

Woodhouse D., United Kingdom. The Constitutional Reform Act 2005 - defending judicial independence the English way, The International Journal of Constitutional Law, vol. 5, 2007 


\section{SYSTEMS OF SELECTION AND APPOINTMENT OF JUDGES AND THE PROBLEM OF JUDICIAL INDEPENDENCE. AMERICAN, ENGLISH AND GERMAN EXPERIENCES}

The article aims to investigate the influence of different systems of selection and appointment of judges adopted in the legal systems of the United States, England and Wales, and Germany on judicial independence. In these countries, the following methods are used for the selection of judges: appointment by the executive, appointment by the career or civil service judiciary, shared or parity appointments and appointment by judicial committees. Comparative law analysis shows that the adoption of a particular method for the selection of judges, especially in connection with the term of office, may have an impact on their independence and impartiality. Especially risky seems to be the American justice system, which rooted in the idea of "popular constitutionalism" methods of election and re-election of judges could jeopardize fair trial guarantees. In England and Wales, of great importance in strengthening the independence of the judiciary was the introduction of the Constitutional Reform Act of 2005 and the institution of the Supreme Court. In Germany, independence of the judiciary is guaranteed by the Constitution and the Constitutional Court. Further observations indicate that both in common and continental law, the universal guarantee of independence of the judiciary is for judges to follow ethical and professional dignity principles.

Keywords: judicial selection, judicial independence, Constitution, fair trial, judicial conduct

Słowa kluczowe: wybór sędziów, niezawisłość sędziowska, konstytucja, rzetelny proces, etyka sędziowska 